

\section{Por que o moderno envelhece tão rápido?}
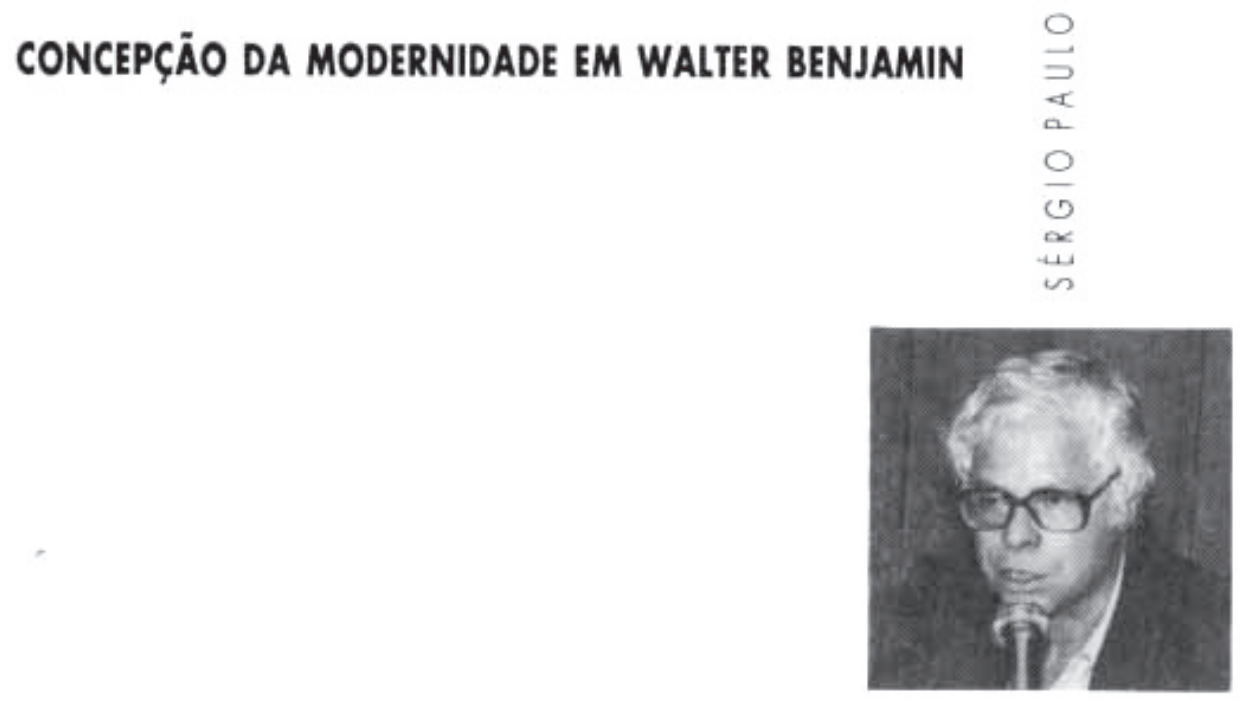

BERND WITTE
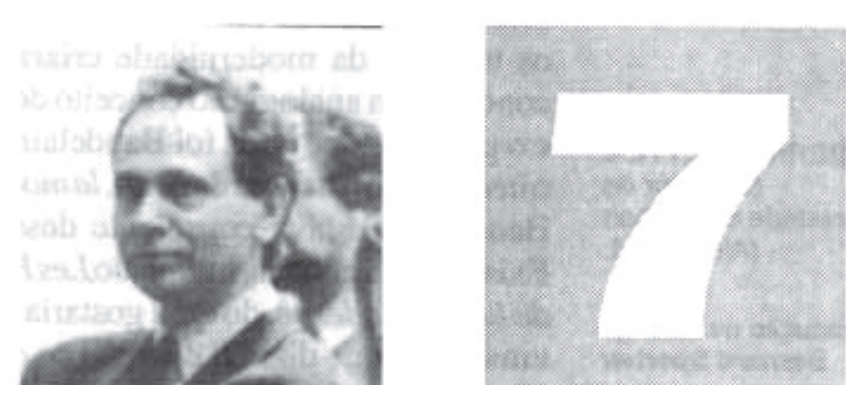


\section{BERND WITTE}

nicialmente, tentarei aproximar-me desta questão do lado histórico, pois se trata de uma questăohistórica. Mas, no final, gostaria também de tratar dos aspectos de atualidade desta questāo, na medida em que estes aspectos me sejam acessíveis, tanto na Europa quanto, talvez, no Brasil.

Tratarei de cinco pontos. O primeiro ponto é sobretudo histórico, já que me referirei à formação do conceito de modernidade literária em Baudelaire. No segundo ponto falarei a respeito da impossibilidade de produtividade e, conseqüentemente, da destruição do sujeito na modernidade. O terceiro ponto trata da modernidade como antigüidade artificial. $\mathrm{O}$ quarto, da modernidade como drama, sendo que aqui deverei tratar das ambivalências da modernidade. Finalmente, no quinto ponto, com o qual pretendo chegar à atualidade, deverei falar sobre o pós-moderno, um tema que se apresenta como bem próximo quando nos perguntamos "por que o moderno envelhece tāo rapidamente".

\section{1) Em primeiro lugar, portanto, a radicalizaçāo da questāo.}

Acho que todos nós pudemos verificar que estas sete questōes que nos foram colocadas são extremamente frutíferas, e que foram colocadas de tal maneira que, por assim dizer, as centelhas saltaram tanto na mesa como no plenário. No caso desta última questāo, sobre "por que o moderno envelhece tão rapidamente", devo dizer que, embora se trate também de uma pergunta formulada corretamente, ela năo o foi com suficiente radicalismo. E não o foi porque no conceito de moderno já está contido dialeticamente oconceitodoenvelhecimento.

Pode-se dizer que, justamente por esse motivo, o que é moderno hoje estará envelhecido ou fora de moda amanhā. Por isso os teóricos da modernidade criaram este conceito em analogia ao conceito de moda,

BERNAD WITTE é professor da Universidade de Aachen (Alemanha).

Traduçăo de George Bernard Sperber e o primeiro que o fez foi Baudelaire. Ele é oinventor da palavra e da coisa, la modernité. Baudelaire estava consciente desse fato. Existe umensaioseu, intituladoLesPeintres de la Vie Moderne, do qual gostaria de citar uma frase, que diz: "Il cherche ce quelque chose qu'on nous permettra d'appeler la modernité; car il ne se présente pas de meilluer mot pour exprimer l'idée en question. Il s'agit, pour lui, de dégager de la mode ce qu'elle peut contenir de poétique dans l'historique, de tirer l'éternel du transitoire" (1). Aqui fica claro que Baudelaire sabe que está usando a palavra pela primcira vez, pois diz que nảo há nada melhor do que esta palavra "modernidade" para exprimir aquilo que estou querendo exprimir, a saber, esta eterna volatilização dos fenômenos.

Benjamin transfere esta palavra para o alemão, onde a palavra Moderne significava inicialmente algo totalmente diferente. Acho que é necessário ver também este aspecto: quando $\mathrm{em}$ alemāo se fala $\mathrm{em}$ Moderne, trata-se na verdade do moderno nas artes, por volta da virada do século, do Jugendstil, ou seja, da arte, da literatura que sc insurge contra o realismo do século XIX. Benjamin é, por seu lado, quem introduz no uso da língua alemã o conceito de modernidade, tal como foi criado por Baudelaire.

Ao mesmo tempo, porém, Benjamin radicaliza o conceito. Em Baudelaire, a modernité nâo é mais do que uma ampliação do conceito tradicional de arte. Esta palavra deve dar expressão à idéia de que também o que há de volátil, o fenômeno quotidiano, deve ser incluído na arte. É isso que Baudelaire denomina de modernité. A respeito disso, quero citar mais uma frase de Baudelaire, no mesmo ensaio já citado: "La modernité c'est le transitoire, le fugitif, le contingent, la moitié de l'art; dont l'autre moitié est l'éternel et l'immuable"(2). Portanto, Baudelaire se atém ainda às leis da arte autônoma. Para ele, ainda existe algo de eterno, imutável, sendo uma metade a arte, e a outra metade é justamente o que há de fugidio, de novo.

Enquanto Baudelaire se atém, ainda, a estas leis eternas, Benjamin pensa a arte na modernidade radicalmente, atendo-se às ordens da moda. A única lei que continua válida para Benjamin é a de que sempre e a qualquer preçoé necessárioonovo, que por sua vez se torna antiquado, com a mesma velocidade. Entendido desta forma, o conceitode modernidade é limítrofe, é um conceito-limiar, dentrodoqual está fixado, antes de mais nada, o fato de que nâo existe uma substância dobeloe de que nảoexiste quaisquer leis de validade geral nem quaisquer valores eternos do estético. 
Até aqui vai o meu primeiro ponto, ao qual quero acrescentar apenas uma breve observaçăometodológica, para chamar a sua atenção sobre a maneira dialéticaambivalente com que Benjamin argumenta neste caso. Pois, embora com seu conceito de modernidade ele negue e esvazie a arte enquanto tal - se considerarmos a modernidade da maneira como ele a vê, $\mathrm{cm}$ verdade não existe mais arte -, ele não deixa de se servir da arte, em primeira linha, de Baudelaire, mas também das representaçōes plásticas, como por exemplo das imagens parisienses de Meyron, para chegar a este resultado. Poder-se-ia dizer que o seu comentário dos poemas de Baudelaire radicaliza aquiloque já está em cerne nesses mesmos poemas. Referindo-nos a nós mesmos, poderíamos dizer de outra maneira que Benjamin ainda tem diante de si uma arte substancial, a de Baudelaire, da qual ele pode se distanciar negativamente na sua reflexão sobre a modernidade. Nós, neste caso, encontramo-nos numa situação diferente. Para nós, por assim dizer, o ponto da negação de Benjamin é o ponto de partida, do qual precisamos nos afastar.

\section{2) A impossibilidade da} produtividade na modernidade, ou o sucídio do sujeito.

Aqui, me referirei sobretudo ao capítulo "A Modernidade" no livro de Benjamin sobre Baudelaire, em que Benjamin descreve Baudelaire como o poeta despossuído, que se apresenta semelhante aolumpesinato. O que é importante para Benjamin, neste contexto, é que o poeta é alguém que não quer trabalhar. Ele descreve com luxo de detalhes of fato de Baudelaire ter apagado os traços de seu trabalho nopoema, assim como descreve que no seu escritório não se podia encontrar nada que aludisse ao trabalho poético. Ele interpreta estes fatos comosignos externos do fato de Baudelaire se ter insurgido contra a categoria central da burguesia, a saber, o trabalho. O trabalho é o centro da vida para o burguês, diz Benjamin, ou, em outras palavras, oburguês confere $\mathrm{cm}$ sua fantasia "uma força criativa sobrenatural ao trabalho". O poeta se vê no papel do antiburguês. Ele prova a possibilidade de existir produção sem trabalho.

Um segundo elemento que Benjamin consegue ler na figura do poeta Baudelaire é o de que o poeta da modernidade é um herói, e ele usa a palavra Heros, ou seja, um herói da Antigüidade. E isso significa, para Benjamin, que o herói antigo que o poeta é a todo instante corre perigo de morte - por assim dizer, até o ponto extremo do suicidio. Em Benjamin podemos ler que "a modernidade tem que estar sob o signo do suicídio". Esta frase que, evidentemente, também é interpretável biograficamente (e eu abro mão de fazê-lo), esta frase tem uma coerência sistemática, a saber, ela alude como signo para o fato de que é impossível que o ser humano se torne criativamente ativo na modernidade. "As resistências que a modernidade opōe ao élan produtivo natural do homem estāo em discordância com as suas forças" - também isto é uma citação de Benjamin. A produçâo da mente ou do espírito, a produçāo cultural, poder-se-ia dizer, tem como meta a efetividade e, com isso, a durabilidade. Mas efetividade e durabilidade são impossibilitadas pelo princípio da modernidade. Pois o que acaba de ser criado é imediatamente algo envelhecido e é vítima do desprezo e do esquecimento.

Por outro lado, porém, na Idade Moderna o sujeito se define justamente a partir de sua força produtiva. O que é um ser humano? Um ser humanoé, segundo a resposta da antropologia moderna, influenciada pela estética do gênio, um ser que, a partir de si próprio, pode produzir algo. Esta condição fundamental da autoconsciência humana na Idade Moderna é revogada pelas características da modernidade. Por isso, a sua auto-extinçảo deve ser entendida enquanto signo, como alegoria da compreensão da própria impossibilidade. Todos sabemos que Benjamin acompanhou esta noção, na prática, até seu último extremo.

Benjamin elabora ainda mais o modelo do poeta visto como herói. Ele apresenta o poeta como apache, quer dizer, como rufiẩo. "Apache" é uma palavra que estava na moda nos anos 20 e que denominava o rufiảo. Um outro papel em que se vê o poeta, nos poemas de Baudelaire, é o de catador de trapos. Contudo, o poeta é sempre descrito como marginal, como alguém que se ocupa das coisas somente e apenas quando elas caíram fora do seu contexto funcional. Isto se torna especialmente claro no símile do poeta e do catador de trapos. Como tal, ele é alguém que está à margem da sociedade burguesa, alguém que se ocupa com as coisas que estāo à margem das concatenaçōes funcionais da sociedade burguesa.

A ligaçāo mais profunda entre o herói da Antigüidade co poeta consiste em que a

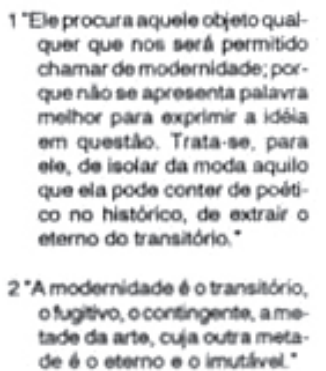

Ee procura aquele objeno qual. chamar de modernidade; por. que $n$ to se apresenta palavr. moihor para exprimir a ideid questaso. Trata-se, para no histórico, de extrair Amodernir tade da arte, cuja outra meta. de 60 oterno 0 o imativel. 
luta de ambos está fadada, desde seu início, ao fracasso. Ambos estão predestinados à perdiçāo. Na modernidade, porém, esta perdiçâocarece da dignidade metafísica que distinguia o herói da Antigüidade. A sua perdiçāo é tão certa quanto absurda. Nisso o poeta, como herói da modernidade, é o modelo e a encarnaçāo daquilo que será também o destino das massas humanas nas grandes cidades, ou seja, uma morte sem sentido.

\section{3) A modernidade como antigüida de artificial.}

Benjamin lê a modernidade como antigüidade. É um velho topos, este, que contrapōe modernidade c antigüidade. Já apareceu no século XVI, na Querelle des Anciens et Modernes. Hans Robert Jauß escreveu longos ensaios a estc respeito $\mathrm{ceu}$ não entrarei $\mathrm{cm}$ pormenores a respeito. Só quero constatar, aqui, que também Baudelaire, no texto já citado, estabelece esta contraposição entre modernidade e antigüidade. Diz Baudelaire: "En un mot, pour que toute modernité soit digne de devenir antiquité, il faut que la beauté mystérieuse que la vie humaine y met involontairement en ait été extraite" (3). Portanto, Baudelaire já constata que a modernidade se torna antigüidade na medida $\mathrm{em}$ que entra $\mathrm{cm}$ contato com a morte.

Issoé explicitado mais amplamente por Benjamin. Antes disso, porém, é necessário verificar que, quando Benjamin acredita que a modernidade pode ser lida como antigüidade, há outra coisa sendo implicada. Para ele isso também significa que a modernidade pode ser lida como texto canônico, como texto sacro. Ou seja, que a funçāo de modeloque a antigüidade tinha é dissolvida e, por assim dizer, recai na modernidade.

A pergunta que se coloca é a seguinte: “Comoé que isso é possível?" Para responder a essa pergunta Benjamin se refere sobretudo às Flores do Mal, de Baudelaire, pois aqui, segundosua análise, Parisse apresenta sob o signo da decadência. À guisa de digressão quero dizer que é claro que isso também poderia ser visto de maneira diferente. A interpretaçäoque Benjamin faz das Flores do Mal é extremamente subjetiva. As imagens da cidade, tal como são desenhadas nas Flores doMal, devem ser entendidas, segundo Benjamin diz no seu capítulo "A Modernidade", "como uma espécie de mímesis da morte". "Aquilo em que a modernidade se aparenta final e mais intimamente com a antigüidade é esta caducidade." E caducidade é, naturalmente, uma outra palavra para morte.

Isso, portanto, é colocado de antemão, $\mathrm{cm}$ primeira instância pela pocsia de Baudelairc. Mas nesse ponto inicia-se a tcoria própria de Benjamin, com a qual vai para muito além do objeto de que ele trata, isto é, Baudelaire. A esse respeito quero citar e comentar algumas frases da obra sobre as galerias, porque elas concernem exatamente a esta questẩo.

Estas frases sāo as seguintes: "Na medida em que o valor de uso das coisas fenece, as alienadas sāo esvaziadas e atra$\mathrm{em}$ significados enquanto cifras. Delas se apropria a subjetividade, na medida $\mathrm{em}$ que nu..s introduz intençōes de desejoe temor". Temos, aqui, novamente o velho modelo do alegorista, que é transferido para o poeta moderno em geral. "Pelo fato de as coisas findas responderem pelas imagens das intençōes subjetivas, estas se apresentam como nảo pertencendo ao passado, como eternas." Isso significa: a modernidade como antigüidade. "Imagens dialéticas são constelaçốes entre coisas alienadas e significaçōes decadentes, que se detêm no instante da indiferença da morte e do significado. Enquanto as coisas são despertadas na aparência para parecerem novíssimas, a morte transforma as significaçōes em antiqüíssimas. âo fazer estas reflexões é necessário considerar que durante o século XIX a quantidade de objetos esvaziados aumenta em quantidade e ritmo nunca dantes conhecidos, poiso progresso tecnológico tira de circulação cada vez mais objetos de uso."

Até aqui vai essa citaçăo mais extensa. Mas acho que ela constitui o centro do contexto a ser tratado aqui. Aliás, essa citação também contém uma certa ironia, na medida em que, nesse trecho, Benjamin cita uma carta de Adorno, a qual passa a comentar. Portanto, o que os senhores acabaram de ouvir é, em parte, Adorno, que novamente responde a Benjamin. Trata-se do contexto de uma discussāo bastante complicada, na qual não quero entrar. Apenas quero comentar brevemente o conteúdo objetivo destas frases. Pois nelas se demonstra até que ponto Benjamin é mais radical e vai além de Baudelaire. Nos tempos antigos, poderia ser dito, o fenecer das coisas e, com ele, a possibilidade de empregá-las como signos em contextos alegóricos, era produ- 
zido mediante processos lentos, como que naturais, ou por catástrofes da natureza. A antigüidade torna-se antigüidade de duas formas: seja por morrer aos poucos, scja por ser enterrada por uma catástrofe natural, e o exemplo mais conhecido disso é naturalmente o de Pompéia e Herculano, soterradas por um monte de cinzas.

$\mathrm{O}$ que, ao meu entender, Benjamin pretende dizer é que a modernidade se caracteriza pelo fato de não mais deixar o envelhecimento e a morte aos cuidados dos processos naturais, mas de colaborar no seu plancjamento e encenação. Este é o processo básico que se impôs durante a industrializaçâo e que também foi transferido para o campo da cultura: as coisas não têm mais tempode envelhecer. (Nesta medida, a questẩo não foi colocada com suficiente radicalismo.) As coisas não têm mais tempo suficiente para envelhecer, mas são produzidas de tal modo que são velhas desde o início $\mathrm{c}$ devem ser substituídas por coisas novas. Neste sentido, os objetos do século XIX, tal como estáo espalhados e são aprecndidos arquitetonicamente nas galerias, são concebidos de antemăo como alegorizáveis c, portanto, como objetos passíveis de serem salvos.

O envelhecimento, se quisermos guardar esta palavra, deve ser entendido como a morte das coisas e dos valores culturais, $c 0$ produzida desde o início. Com isso, porém, entramos num contexto inteiramente novo, que vai para muito além do que Baudelaire dissera de início. Para resumir, gostaria de dizer que, para Benjamin, a antigüidade, neste confronto com a modernidade, não é mais entendida como um modelo que dita normas, mas como o mundo dos homens, sucumbido e marcado pela morte. A diferença fundamental é a seguinte: a antigüidade histórica transformou-se em tal devido a processos ou catástrofes naturais; na modernidade oprocessode perecimentoestá incluído no processo de produção, ou seja, na forma da produçāo material. A novidade reside justamente nesta noçāo; ela é, por assim dizer, a componente materialista da teoria benjaminiana da modernidade.

\section{4) A ambivalência da modernidade.}

Com essa expressão quero dizer que o conceito de modernidade encerra um paradoxo. Sergio Rouanet salientou expressamente, em sua exposição, que com Benjamin todos os fenômenos assumem este ca- ráter ambivalente, o caráter simultâneo de utopia e de mito, de promessa e de infernalidade. Dessa maneira poder-se-ia dizer que a modernidade é a síntese conceitual de todos estes fenômenos do século XIX. Nela estão expressos simultaneamente o positivo e o negativo. A modernidade é o inferno - esta frase de Benjamin já foi citada aqui repetidas vezes - mas enquanto tal é simultaneamente apocalíptica. Quer dizer que, por ser tăo abjeta, por ser vista de forma tảo negativa, elaé vista por Benjamin comotendo a maior proximidade possível com a salvação. Ela é indício de salvação futura.

Também a respeito deste aspecto gostaria de citar algumas frases do fascículo $\mathrm{N}$ da obra sobre as galerias. Numa delas, Benjamin fala da felicidade, a qual, para ele, serve sempre para definir simultaneamente salvação ou fim da história: "A felicidade

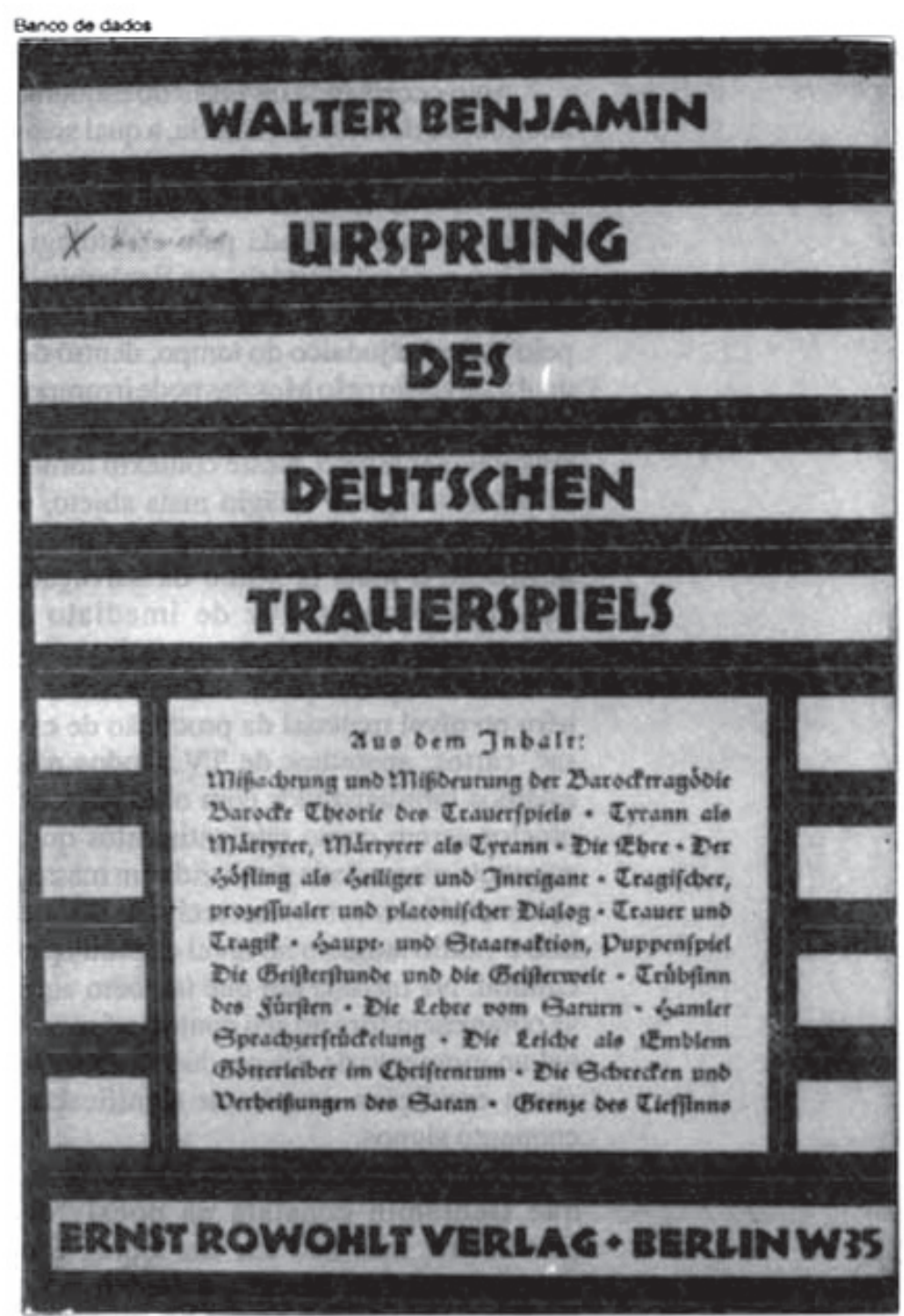


só é imaginável para nós no ar que respiramos, entre os homens com quem convivemos". Esta é uma frase muito típica de Benjamin. Ela começa com uma observaçāo muito singela, tirada, como quem diz, da vida cotidiana: só podemos imaginar a felicidade como algo que nós mesmos já vivenciamos. Para nós, não há felicidade no passado. "Em outras palavras, com a noçāo da felicidade vibra em nós a imagem da salvaçāo - e é isso o que nos ensina aquele peculiar estado de coisas. Esta felicidade está embasada justamente no desconsolo e justamente no abandono que foram os nossos. Nossa vida é, dito de outra forma, um músculo que tem força suficiente para contrair todo o tempo histórico; ou, ainda de outra forma, a concepçāo legítima do tempo histórico descansa integralmente na imagem da salvaçāo." Em correlaçāo com essa citação poderíamos dizer que a modernidade, enquanto tempo mais próximo da salvação, é messiânica ou se defronta com a salvaçảo porque destrói $a$ priori o contexto natural que representa o inferno.

Aqui ocorre uma inversāo do esquema habitual do decurso da história, a qual sempre imaginamos como algo que corre $\mathrm{em}$ direção a uma meta. Esta noçāo está muito evidentemente marcada pela escatologia cristā. A noçāo de história, em Benjamin, à qual eu me refiro, é muito mais marcada pelo conceito judaico do tempo, dentro do qual a salvação pelo Messias pode irromper a qualquer momento, a qualquer instante $\mathrm{e}$ em qualquer tempo. Neste contexto tornase plausível que o estágio mais abjeto, o estágio da modernidade, possa ser simultaneamente o mais próximo da salvaçāo, porque ele co-produz de imediato a antinatureza, a mímesis da morte. Isso tanto no nível da produçäo de bens, como também no nível material da produção de casas, carros, aparelhos de TV. Todos nós estamos familiarizados com o fato desses objetos serem como que natimortos que, enquanto mercadoria produzida em massa, sâo concebidos como descartáveis. Só que isso é válido também no nível da produção cultural. Na medida em que também aqui as obras caem fora do seu contexto funcional no momento de sua produção, elas ganham condiçōes de admitir significaçāo enquanto signos.

A falta da natureza e da ingenuidade, que Benjamin constata na poesia de Baudelaire, mas nāo em sua teoria, é o motivo teórico de sua própria redefiniçāo da modernidade. Também por esse motivo, por exemplo, a lésbica é, para Benjamin, a verdadeira heroína da modernidade - fato que só quero mencionar, mas nāo interpretar. Com isso voltamos às questōes de que tratamos ontem à noite, a saber, que Benjamin também era um marginal no campo sexual, coisa que pode ser confirmada repetidas vezes. Também aqui ele retoma motivos baudelairianos. Mas por que a lésbica é a heroína da modernidade, como diz Benjamin em seu livro sobre Baudelaire? Porque, na figura da lésbica, a mulher, que em geral é vista como a encarnação $\mathrm{e}$ a guardiA da vida natural, se me for permitida essa expressāo, aparece inserida num contexto antinatural, num contexto contrário à natureza.

Neste contexto, Benjamin cita uma lésbica francesa do século XIX - ele costumava desencavar esse tipo de trechos obscuros -, uma certa Claire Demar, que proclama: "Chega de maternidade! Chega das leis do sangue!". E é justamente disso que se trata na modernidade, da luta contra a maternidade, da luta contra as leis do sangue, na medida $\mathrm{cm}$ que é nelas que a vida natural encontra a sua plenitude.

O momento da morte, inserido no processo de produçāo da modernidade, tornaa uma época de antinatureza, o que se exprime na arte moderna pelo fato de nela as coisas se tornarem alegorias. Benjamin mostra isso, por exemplo, nos quadros de Meyron, que representou Paris como uma cidade dos mortos, o que é visto por Benjamin como um exemplo típico da superposiçāode antigüidade e modernidade na alegoria. Aqui é necessário se perguntar: oque é que as coisas representam alegoricamente na modernidade? E a única resposta possível é: elas se tornam signos alegóricos da caducidade e mortalidade do homem e do mundo e, através disso, da sua necessidade de salvaçăo.

A modernidade se apresenta, portanto, como drama no sentido mais verdadeiro. "A modernidade heróica", diz Benjamin, "ć um drama, no qual o papel de herói está em disponibilidade". O papel de herói está em disponibilidade porque todos têm que interpretá-lo. Todo homem tornou-se, por assim dizer, um herói neste drama, no qual o mundo, tal qual no drama barroco, está fadado à morte e é, portanto, privado de consolação. Mas, ao mesmo tempo, o mundo é prenhe de significado e portanto, passível de salvaçāo. 


\section{5) O último ponto consiste na seguinte questāo: encontramo-nos ainda na modernidade ou já estamos em pleno pós-moderno?}

No processo de envelhecimento da modernidade, na caducidade e mortalidade nela institucionalizadas e que são simultaneamente a sua antinatureza, o niilismo da história fazoseu auto-retrato. Esse niilismo, que foi formulado pela primeira vez por Nietzsche em seu Nascimento da Tragédia como sendo o motivo de toda história, é suportadode forma heróica na modernidade porque ele prenuncia a sa!vação. Em Nietzsche, essa salvação é vista esteticamente. "O mundo se justifica pelo fato de somente poder ser justificado esteticamente", diz Nietzsche. Em Benjamin, assim como em Marx - e nisto Benjamin é decididamente marxista -, a avaliação é feita em termos da escatologia, e a total nulidade do mundo mau é visto como signo de sua iminente salvação. Esta espécie de esperança se nutre da experiência das revoluçōes de 1789,1848 e 1871 . No caso de Benjamin fica perfeitamente claro que ele sempre recorre a este modelo francês de revoluçāo. Nutre-se, porém, também, das expectativas nascidas a partir da revoluçāo de 1917. É bom que se diga que esta época das revoluçöes européias já chegou ao seu fim na década de 30, a saber, com o triunfo do nacional-socialismo c com os processos stanilistas. Benjamin também via a situação dessa mesma forma. Para nós, esta época chegou definitivamente ao seu fim em 1989 , com o descalabro do "socialismo real”, duzentos anos após seu começo.

Penso que chegamos, de fato, ao final da modernidade, na medida em que este modelo de revoluçāo, que durante duzentos anos foi portador da história mundial, hoje não comporta mais nada. Esta esperança numa mudança a partir de uma revoluçẩo que trouxesse uma ordem social nova e inteiramente diferente foi enganosa. Com isso, a modernidade envelheceu definitivamente. A revolução de 1989 é apenas uma revolução aparente, na medida em que o velho mau, e com estes termos me refiro claramente ao sistema de livre mercado, triunfou sobre o sistema ainda pior, o stanilismo.

A arte ou os valores espirituais ou culturais não tiveram, aqui, qualquer papel. Como Jean Baudrillard constatou corretamente, a arte foi hoje em dia catapultada para a esfera da simulaçăo e não tem mais nenhuma influência sobre os processos políticos ou sociais. O desamparo dos escritores na ex-RDA, que foram, a bem dizer, os motores iniciais desta revolução, desta mudança das circunstâncias, este desamparo dos escritores hoje em dia, ante o atual processo de reunificaçāo, mostra isso com toda clareza, segundo me parece. Os vencedores desta revoluçāo sāo a Siemens e a Deutsche Bank. Eu diria que este é o estágio da modernidade européia hoje, um estágio que, neste sentido, não é mais modernidade, mas pós-modernidade.

Se vocês permitirem, vou tentar fazer algo a que me atrevo com toda espécie de reserva, porque não conheço o país. Vou tentar relacionar as poucas impressöes que consegui captar nesta cidade com o conceito de modernidade, com o intuito de perguntar (e, por favor, entendam isto apenas como pergunta) se aqui ainda existe algo assim como o moderno, ou se também o Brasil se encontra na era do pós-moderno. Para tanto, quero partir das impressōes que colhi. Vi São Paulo pela primeira vez da janela de meu hotel, e devo dizer que São Paulo parece uma cidade dos mortos, à maneira de Benjamin. De fato isso pode ser dito desta forma porque, vista do alto de um edificio de trinta andares, a cidade se apresenta ao observador como um submundo, como um reino das sombras, no qual os arranha-céus, em sua uniformidade, se apresentam como lápides num cemitério. E quando a gente passeia pela cidade, vê-se logo o inacabado e o que já está decaindo. Do lado do nosso hotel há um edifício alto, no qual a gente não fica sabendo se ainda está em construção ou se já está caindo aos pedaços, se já houve gente que morou nele, ou se ainda está para ser habitado. No momento, quem habita essa construção sảo os pássaros.

Portanto, é possível fazer aqui observaçōes muito semelhantes às que Benjamin fez a respeito da Paris do século XIX. Mas eu penso que nãoé mais possível tirar qualquer consolo metafísico a partir destas observaçōes. É a uniformidade do permanentemente uniforme o que ficou cristalizado aqui também enquanto arquitetura. Poder-se-ia dizer que faltam os traços da história, no sentido de algo que confira sentido a isto tudo, no sentido da memória de uma vida bem-sucedida, tal como ainda existe nas cidades européias, sobretudo na Paris que Benjamin conheceu, apesar das 
destruiçōes nelas provocadas pela modernidade. Tentar denominar os inexpressivos conglomerados de arranhacéus, ou mesmo as favelas, de ruínas seria um absurdo, porque uma ruína pressupōe uma forma bem-sucedida, cuja existência ela lembra através do modo de sua deficiência. Esta cidade aqui apresenta o rosto inescrutável da vida pululante, no qual nem o mais habilidoso vasculhador de pistas, como Benjamin o era, poderia encontrar qualquer vaticinio de felicidade.

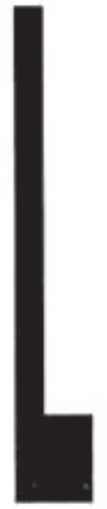

\section{SERGIO PAUIOROUANET}

ogicamente, essa pergunta está subordinada a uma pergunta prévia: existe, em Benjamin, uma concepçăo da modernidade?

Em geral, Benjamin nāo reflete sobre a modernidade, limitandose a descrever certos aspectos da vida social dentro da modernidade.

Assim, cle se refere constantemente às experiências do homem moderno no novo universo urbano. Em parte, essas reflexōes se baseiam nos comentários de Baudelaire sobre o "heroísmo moderno". Para o autor das Fleurs du Mal, para viver a modernidade é necessária uma constituiçāo heróica. As pressōes que a vida moderna impōem ao homem são tais, que a mera sobrevivência exige forças superiores às dos personagens de Homero. Já Balzac tinha comparado um dos seus personagens, um simples caixeiro-viajante, a um gladiador da antigüidade. Nucingen e César Birotteau superam em coragem Ajax e Aquiles. Para Baudelaire, basta ler a Gazette des Tribunaux e $\mathrm{O}$ Moniteur para sentirmos, no destino dos grandes criminosos, o heroísmo que é próprio à nossa época. $\mathrm{A}$ modernidade é nosso destino, nosso heroísmo consiste em enfrentar esse destino, como na tragédia antiga, $e$ muitas vezes o suicídio é o último gesto de heroísmo possível ao homem moderno. "As resistências que a modernidade opōe ao impulso produtivo natural do homem são desproporcionais às suas forças. É compreensível que paralisado, ele se refugie na morte. A modernidade deve estar sob o signo do suicídio... Esse suicídio nāo é renúncia mas paixāo heróica. É a conquista da modernidade na esfera das paixōes" (1). $\mathrm{O}$

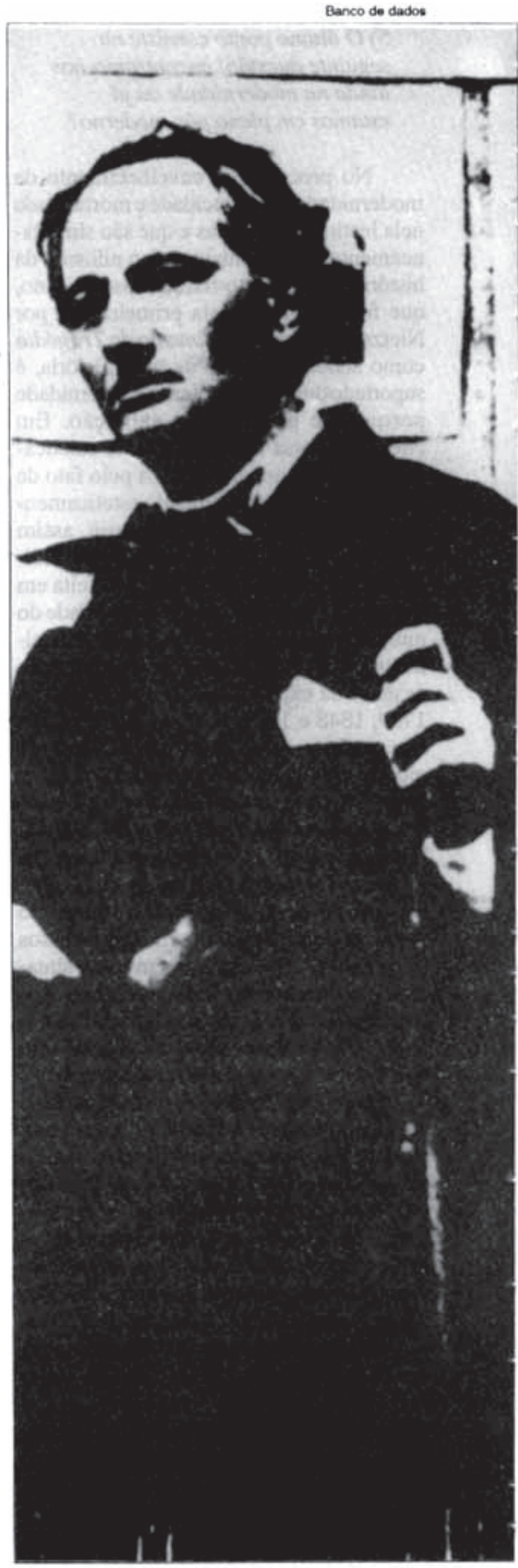

o FaANCES chaAles BaUdelaiaE 
herói moderno está predestinado ao fracasso. Ele não está previsto pela modernidade, que se revela como sua desgraça, sua má estrela.

Benjamin aceita $\mathrm{em}$ parte essa concepçăo do "herói moderno": é o homem da cidade grande, duclista da multidāo, que anda pela massa dando $\mathrm{e}$ recebendo estocadas, dando e recebendo choques. A onipresença das situaçōes de choque introduziu na sensibilidade humana uma alteração qualitativa. O herói da multidão $t e m$ mais consciência que memória, é mais capaz de perceber que de lembrar-se, é mais sensível ao descontínuo da vivência que à continuidade da experiência. $\mathrm{O}$ órgāo da vivência é a percepçảo, capaz de interceptar choques, enquantooórgāo da experiência é a memória; no mundo moderno todas as energias psíquicas têm que se concentrar na consciência imediata, para interceptar os choques da vida quotidiana, oque envolve o empobrecimento de outras instâncias, como a memória, e com isso o "herói moderno" perde todo contato com a tradiçāo, transformando-se numa vítima da amnésia (2).

É nessa experiência do choque que Benjamin baseia em grande parte sua descrição da estética moderna. É o caso do cinema: o filme é a forma de arte correspondente à estrutura choquiforme do mundo contemporâneo. "Nisso consiste o efeito de choque do filme, que como todo efeito de choque tem que ser interceptado por uma concentraçăo mais intensa da consciência... O cinema é a forma de arte correspondente ao perigo de vida, cada vez mais ameaçador, que o homem de hoje precisa enfrentar"(3). É o caso, em geral, da arte moderna, uma arte pós-aurática. $\mathrm{O}$ fim da aura é um subproduto das técnicas modernas de reproduçăo, que destruíram a distância (Entfernung) e o caráter único (Einmaligkeit) das obras. Mas é também um fenômeno social, e nảo somente tecnológico: a obra não-aurática se funda justamente no novo tipo de percepçăo do homem moderno, voltado para a vida presente, para a proteção contra os riscos da cidade grande, para a vivência, para a proximidade.

O declínio da aura se baseia "em duas circunstâncias, que coincidem com a importância crescente das massas na vida de hoje: fazer as coisas se acercarem, humana e espacialmente, é uma preocupação tảo apaixonada das massas atuais com sua tendência a superar a unicidade dos fatos..."(4).

Enfim, Benjamin tenta descrever a estrutura temporal do coletivo no mundo moderno. Por um lado, o mundo moderno está sob o signo do novo. É o novo a serviço do volume de vendas, o novo da mercadoria, da moda, cuja única funçāo é multiplicar o consumo. É a temporalidade descrita por Berman, a de um mundo sempre sujeito ao fluxo, $\mathrm{em}$ que nada é durável, $\mathrm{cm}$ que as cidades se desfazem e refazem, um mundo em que "tudo o que é sólido desmancha-se no ar" (5). A modernidade é o novo que expulsa o antiquadoe se define mesmopelo distanciamento com relaçâo ao antiquado. "Não houve declínio das passagens, mas transformação. De um golpe elas se converteram na fôrma vazia (Hohlform) a partir da qual a imagem da modernidade se fundiu. Nelas o século exibiu com arrogância seu passado mais recente" (6). Por outro lado, nada muda nesse mundoem que tudo muda. O mundo moderno tem dentro de si o passado c busca relacionar-se com a antigüidade. "De todas as relaçōes $\mathrm{cm}$ que a modernidade ingressa, a mais eminente é a relaçâo com a antigüidade... A modernidade designa uma época; designa ao mesmotempo a força que trabalha nessa época, assimilando-a à antigüidade" (7). Sujeito inexoravelmente à gravitaçăo do velho, 0 mundo moderno nảo pode produzir o verdadeiramente novo. Por isso Benjamin pode dizer que "a modernidade contém em seu bojo a antigüidade, como um demônio que a assaltasse durante osono" (8). Otempoda modernidade é a síntese dos dois tempos: o novo como sempre-igual, o sempre-igual no novo. Éo tempo do capitalismo, em que as forças produtivas se renovam no interior de relaçōes de produçāo inalteráveis. O que deveria ser mantido se perde para sempre "tudo o que é sólido desmancha-se no ar". oque deveria transformar-se se conserva. $\hat{E}$ um mundo em que onovoé sempre arcaico, $\mathrm{cm}$ que o arcaico aparece com os traços do novo - o tempo do inferno. "Definição da modernidade como o novo no contexto do que sempre foi... A modernidade como o tempodo inferno. As puniçöes infernais são em cada caso o mais novo que existe nesse domínio. Nảo é que sempre a mesma coisa aconteça, nem se trata, muito menos, do eterno retorno. Trata-se do fato de que o rosto do mundo nunca muda justamente no que é o mais novo, de que esse novo sempre permanece o mesmo, em todos os seus ele-

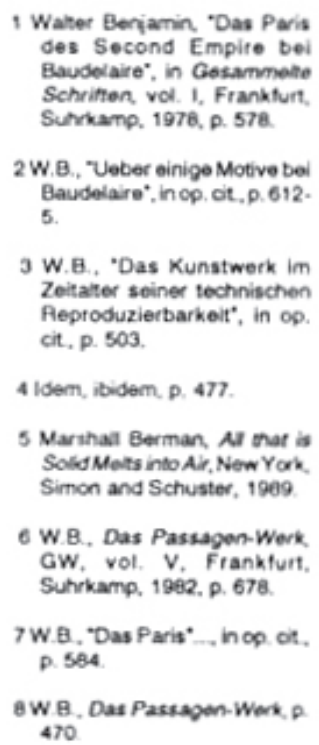
des Second Empire bei Baudelaire", in Gosammette Schritten vol. 1. Frankfurt. Sumkanp, 1976, D. 578.

2 W.B., Ueber ainige Motive bei Baudelaire", in cp, ot, p. 612 . 5.

3 W.B. "Das Kunstwerk im Zeitater seiner technischen Peptoduzierbarkeit", in $\propto$. cit, p. 503.

4 idem, ibidem, p, 477

5 Marihas Berman, Mat that is Sold Meits into Al, New York. Simon and Schuster, 1909

6 W. B, Das Pasugan-Werk GW, vol. V. Frankfurt, Suhrkamp, 1982. p. 678.

7 W. B. "Das Paris". in on ot. D. 584 . 8W. B, Das Passagen-Werk, 
Idem, ibidem, DQ 676 a 1010

$10 \mathrm{Cl}$ principalmanto Max Weber, Gesammelte Aufsaefze $z$ ut Aeligions. soziologie, Tuabingen, J C Mohe, 1978

11 * Com cada aumento do racionalismo da ciencia ampíriça a religiâo do crescentemente expuisa do reino do racional e relegada ao irracional, transtormandoe em peral na estera irraciocolou gers racional das for malcu antiracional das forças. op cit, vol 1.p. 564 .

12 Idem, itidem, p. 203

13 Idem, ibidem, p. 204

$14^{\circ} \mathrm{O}$ que é tâo dificil ao homem moderno e principalmente as novas geraçbes b estar a al. tura de entrentar osse quob. diano... E uma fraqueza nao poder olhar de frente o dest. no de nossa bpoca. E Edest. no de noese ternpo. com processos de racionalizaçato - intelectualizaçâa que the sao proprios, se sobretudo com os processos de desencantamento, que justamente os valores útimos a mais supublico Devo-so dizor quem naso puder suporta masculamente esse destino do tempo, que regresse ... aot braços compassivos e largamonto abertos das antigas Igrejas. Max Weber. "Wissenshall als Berur". in Wisammomo Aulsaetze $z$ Wissonschatislehio. Tuebingen, J. C. B. Moht. 19e5, pp. 605 e 612

15 W. B. Das Passagen. Werk. P. 494

16 Idem, ibidem, pp. 678.9.

17 Idem, ibidem, p. 680 .

18 Idem, itodem, p. 266

19 Idem, ibidem, pp. 511.23

20 idem, loidem, p. 272

21 Idem, Bodem, p. 517

22 idem, Bidem, 495 mentos. Isso constitui a eternidade do inferno. Determinar a totalidade dos traços em que a modernidade se manifesta significaria descrever o inferno" (9).

Por mais sugestivas que sejam essas intuiçöes, elas são justamente isso: intuiçổes. Sentimos falta de uma visāo estrutural da modernidade, como ela foi desenvolvida por Weber, uma concepçâo que nâo se esgote numa descrição de fenômenos dentro da modernidade mas que tenha como objeto a própria modernidade.

Ora, tenho a impressāo de que o Trabalho das Passagens contém exatamente a armação desse conceito estrutural de modernidade, e mais ainda: de que ela se constitui através de um diálogo implícito com Weber.

Sabemos que para Weber a modernidade é o produto de processos de racionalização que se desdobraram no Ocidente a partir da Reforma Protestante, e que incluem processos de racionalizaçāo cultural e social.

A racionalização cultural levou à diferenciaçāo das esferas de valor (ciência, arte, moral, direito), inicialmente embutidas na religiẩo, e à dessacralizaçāo ou desencantamento (Entzauberung) da tradiçāo, depurada dos seus elementos míticos.

A racionalizaçảo social se manifestou, entre outras esferas, na vida econômica, caracterizada pelo cálculo racional dos custos, pela institucionalizaçāo do trabalho assalariado, por uma ideologia intramundana que favorecia o processo de acumulação e pela contínua incorporação da ciência e da técnica ao processo produtivo (10).

Essencial na teoria weberiana da modernização é $\mathrm{cm}$ primeiro lugar o pressuposto de que existe uma relação inversa entre a esfera mítico-religiosa e a esfera da técnica e da economia. Onde a tradiçāo religiosa permanece hegemônica não há processos cumulativos de desenvolvimento técnico; onde esses processos se desenvolvem, juntamente com o saber empírico que os viabiliza, nâo há tradiçāo religiosa intacta. Em outras palavras, o progresso econômico e técnico, possibilitado pela Entzauberung, é ao mesmo tempo agente da Entzauberung, pois cada avanço do conhecimento empírico e da dominação sobre a natureza representa um recuo do universo mítico (11).

Em segundo lugar, Weber vê sem entusiasmo essa dialética da racionalizaçāo econômica e da racionalizaçāo cultural. A Entzauberung, para ele, levou a uma perda de sentido, Sinnverlust, e o progresso técnico-cconômico a uma perda de liberdade, Freiheitsverlust, a uma configuração social que aprisiona o homem numa "gaiola dura comooaço", num stahlhartes Gehāuse (12), na qual nāo há mais lugar para os ideais éticos que embalaram o berço do capitalismo nascente e que a todos transforma em "especialistas sem inteligência e em hedonistas sem coraçāo" (13).

Em terceiro lugar, Weber recomenda, como resposta a essa modernidade desumanizante, uma ética do amor fati. A vida racionalizada é o destino do homem, e temos que ser suficientemente viris para aceitar, sem ilusỏes políticas ou religiosas, o caráter inelutável desse processo (14).

Cada um desses três pontos contém uma faceta da atitude weberiana com relaçāo à modernidade. O primeiro a descreve, o segundo a avalia e o terceiro propEe uma ética, ou uma política, da modernidade.

Ora, Benjamin se opōe, ponto por ponto, a essas posiçōes weberianas.

Primeiro, ele recusa a descrição, dizendo que a modernidade tal como ela se deu historicamente representa o reino do mito e nāo o do desencantamento. Em vez de despertar o homem do seu sonho mítico, a modernidade capitalista o mergulhou numa nova mitologia. "O capitalismo foi um fenômeno da natureza que submeteu a Europa a um Traumschlaf, a um sono povoado de sonhos e provocou a reativaçăo das forças míticas" (15). Uma coletividade sujeita a esse sono, acrescenta Benjamin, "nâo conhece história. Ela recebe o fluxo da história como sempre igual e como sempre novo. Tanto a sensação do novo e do moderno como o eterno retorno do idêntico constituem as formas da história de sonho" (16). Esse sonho coletivo se manifesta em todas as figuras culturais do século XIX: na moda (17), no interior (18), nos cassinos e museus, que Benjamin chama Traumhauser, casas de sonho (19), nas passagens (20), e na própria cidade em que se situam todos esses objetos e atividades, na Paris como cidade de sonho, Traumstadt (21). Todos esses sonhos emanam do "corpo"docoletivo, de sua base material: a infraestrutura se exprime na consciência coletiva do mesmo modo que as sensações somáticas do indivíduo adormecido se exprimem no conteúdo do sonho (22). As novas técnicas, longe de abolirem o mito, 


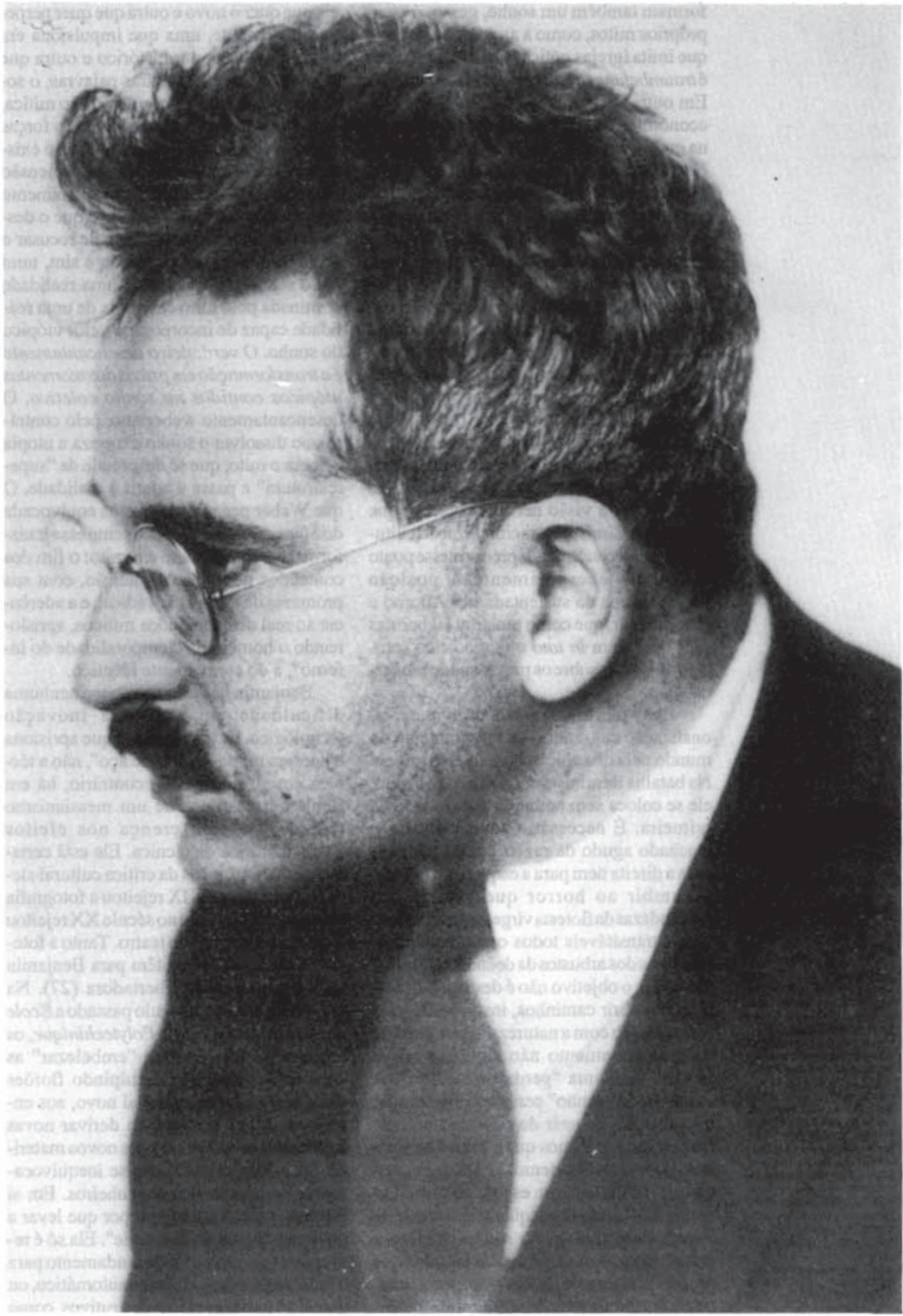


23 idem, bidem, p. 213

24 W.B. Unber den Beprill der Geschichte, GS, vol. I. p. 701

25 Juergen Habermas, Theorie des hommunikatien Hundes. Frankturt, Suhrkamp, 1001.

26 W.B., Das Passagen. Werk p 571

27 O valor politico da fotogyafa está para Beriamin no tato de que "por suas caracteristicas tícnicas, a fotografia pode e deve subordinar - $s e$ a um seo mento termporal especifico (duraçấo do periodo de exposicáol em contraste com a pintura Sua significactopo piti a, nesse precisalo cronológica". WE op. cit, p. 844. Quanto ao cl nema, seu valor politico est em constituir um voiculo par a mobilizacjo das massas. nascondiobes modifcadna do que exigem a dispersâ. (Zerstroungt o ndo o rocolh. mento (Sammingt). WB, Das Kunstwerk, in $\infty$ of , P. 460

$28 \mathrm{Ct}$. particularmente "Konvolut I, Ecole Polytechnique" in Das Passagen-Work, po. 9e2-9. formam também um sonho, geram os seus próprios mitos, como a arquitetura de ferro que imita igrejas góticas: também a técnica étraumbefangene, prisioneira dosonho(23). Em outras palavras, o progresso técnico e econômico não marcha, como para Weber, na mesma direçăo que o progresso cultural. Não há mais uma relaçăo inversa entre mito e modernidade técnico-econômica. Esta não gera nenhuma Entzauberung, mas engendra fantasmagorias sui generis, sujeitas à temporalidade do mito, à do sempre igual. Em conseqüência, a modernidade näo somente não significa o fim da magia como significa a radicalização do universo mágico.

Segundo, Benjamin recusí a avaliação, distanciando-se assim do pessimismo de Weber. Se Benjamin rejeita o progresso como ideologia, como fundamento de uma filosofia da história baseada num tempo vazio e homogêneo (24), ele não partilha com Weber a visão neoconservadora que vê com pessimismo a racionalização culturale asocioeconômica. Éprecisonesse ponto distinguir energicamente a posiçâo benjaminiana da sustentada por Adorno e Horkheimer, que como mostrou Habermas (25) aceitaram in toto o diagnóstico sombriode Weber sobre os processos de modernizaçăo.

Benjamin advoga sem reservas a racionalização cultural, o desencantamento do mundo pela dissoluçāo do universo mítico. $\mathrm{Na}$ batalha iluminista entre a razão e o mito, ele se coloca sem ambigüidade do lado da primeira. É necessário "avançar com o machado agudo da razäo, sem olhar nem para a direita nem para a esquerda, para não sucumbir ao horror que avança das profundezas da floresta virgem. Arazāodeve tornar transitáveis todos os terrenos, limpando-os dos arbustos da deência e do mito" (26). Mas o objetivo nāo é destruir a floresta, e sim abrir caminhos, instaurando uma nova relação com a natureza. É por isso que o desencantamento não significa em si mesmo nenhuma "perda de sentido". A metáfora do "sonho" permite compreender o caráter sui generis do desencantamento benjaminiano. Vimos que o mito é equiparado ao sonho. Mas temos agora que acrescentar: o sonho não se esgota no mito. Levando às últimas consequêências a teoria de Freud, Benjamin vê no sonho coletivo o entrelaçamentode duas instâncias, uma que produz imagens de desejo e outra que censura e dissimula essas imagens, uma instân- cia que quer o novo e outra que quer perpetuar o existente, uma que impulsiona em direçảo ao despertar histórico e outra que eterniza o sono. Em outras palavras, o sonho do coletivo tem uma dimensão mítica, sem dúvida - é a correspondente às forças que se opōe ao desejo e defendem o existente - mas tem também uma dimensāo utópica. Se é assim, o desencantamento benjaminiano é mais complexo que o descrito por Weber. Não se trata de recusar o sonho em nome da realidade e sim, num certo sentido, o de recusar uma realidade dominada pelo mito em nome de uma realidade capaz de incorporar o vetor utópico do sonho. $O$ verdadeiro desencantamento éatransformaçäoem práxis dosmomentos utópicos contidos no sonho coletivo. $\mathrm{O}$ desencantamento weberiano, pelo contrário, ao dissolver o sonho exorciza a utopia e libera o mito, que se desprende da "superestrutura" e passa a aderir à realidade. $\mathrm{O}$ que Weber percebeu na forma equivocada doSinnverlust foi simplesmente essa transformaçāo da realidade em mito: o fim dos conteúdos utópicos da tradição, com sua promessa de renovação radical, $\mathrm{e}$ a aderência ao real dos conteúdos míticos, aprisionando o homem na "temporalidade do inferno", a do eternamente idêntico.

Benjamin nāo tem tampouco nenhuma dificuldade em accitar a inovação tecnológica. É o capitalismo que aprisiona o homem numa "gaiola de aço", não a técnica em si mesma. Ao contrário, há em Benjamin vestígios de um messianismo técnico, de uma crença nos efeitos emancipatórios da técnica. Ele está certamente nos antípodas da crítica cultural alemã que no século XIX rejeitou a fotografia $\mathrm{em}$ nome da pintura e noséculo $\mathrm{XX}$ rejeitou o cinema em nome do teatro. Tanto a fotografia como o cinema têm para Benjamin uma clara vocação libertadora (27). $\mathrm{Na}$ querela que opôs no século passado a Ecole des Beaux Arts à Ecole Polytechinique, os arquitetos, que queriam "embelezar" as construçōes de ferro esculpindo florōes neoclássicos nesse material novo, aos engenheiros, que pretendiam derivar novas formas das propriedades dos novos materiais (28). Benjamin coloca-se inequivocamente no campo dos engenheiros. Em si mesma, a técnica não tem por que levar a qualquer "perda de liberdade". Ela só é repressiva quando serve de fundamento para o mito do progresso linear e automático, ou quando é usada para fins destrutivos, como 
na guerra. Inscrita em novas relaçôes sociais, ela seria instrumento de um "trabalho, que, longe de explorar a natureza, libera as criaçốes que dormem, como virtualidades, em seu ventre" (29).

Terceiro, nada mais longe de Benjamin que umaética neo-nietzschiana de aceitação do mundo moderno como destino. É a posição de Weber, como vimos. Para ele, esse destino deve ser suportado com estoicismo "másculo". Weber ilustra essa ética com um contra-exemplo, odos judeus, que crêem na possibilidade de que odestino venha a ser vencido pelo Messias. "Guardiāo, quanto tempo durará ainda a noite? O guardião diz: a manhã virá, mas ainda é noite. Se quiseres perguntar, volta de novo." Essa parábola judaica, citada por Weber, simboliza para ele uma atitude irresponsável. A pergunta traduz uma esperança utópica, um Sehnen e um Harren, uma tenacidade, uma aspiração, cujo único efeito é desviar a atençấo do homem das Forderungen des Tages, das exigências do quotidiano (30).

Para Benjamin, não se trata de aceitar o destino, mas de desafíá-lo, e ele o faz recorrendo precisamente às categorias do pensamento judaico e do messianismo judaico, que Weber rejeita. Mas a parábola de Weber exprime um tipo de messianismo que é o oposto do desejado por Benjamin. Ela ilustra o messianismo da espera, do Sehnen e Harren, em tudo semelhante ao do historicismo, dacontinumm social-democracia e do marxismo ortodoxo: o que se baseia nodeterminismoda etapa, pressupondoque o amanhả só raiará no momento certo, consumados os tempos e amadurecidas as condiçōes objetivas. É o messianismo do tempo contínuo, enquanto o Messias de Benjamin quer romper o continuum, dinamitá-lo, para despertar os mortos e salvar os passados oprimidos. Estranhamente, a mesma fantasia sexual permeia a ética da recusa, de Benjamin, e aćtica da aceitaçãoestóica, para Weber: a fantasia da virilidade. Também para Benjamin é preciso ser viril, mas a virilidade nảo consiste $\mathrm{em}$ dizer sim à modernidade perversa e sim em recusá-la. $\mathrm{O}$ historiador dialético "deixa a outros a tarefa de se esgotar nobordel dohistoricismo, com a meretrizera uma vez. Ele fica senhor das suas forças, suficientemente másculo para fazer saltar pelos ares o da história" (31).

Aparece assim, nas entrelinhas desse diálogo implícito com Weber, uma concep- ção alternativa de modernidade. Weber se preocupa apenas com a descrição da modernidade "real", a que se realizou sob o capitalismo. Benjamin critica essa descrição, como vimos. Mas além disso, ele faz algo de inconcebível para Weber: opöe à modernidade empírica uma modernidade normativa, que só poderá realizar-se com a mudança das relaçōes sociais.

Na modernidade normativa, esboçada pelo lluminismo, a técnica está a serviço do homem e a esfera cultural é autenticamente secularizada, ou seja, o homem se liberta do mito e as energias utópicas da tradiçāo migram para a esfera da práxis, historicizando-se. A modernidade realizada pelo capitalismo se afasta do modelo normativo, porque nela a técnica é instrumento de opressão e a esfera cultural secularizou-se no pior sentido, deixando intacto o mito, que agora se confunde com a realidade, e esvaziando os potenciais utópicos da tradiçāo. Adistância entre a modernidade teleológica e a modernidade real abre um espaço para a crítica - o real é denunciado à luz do normativo - e para a utopia - cla torna visíveis os contornos de uma "outra" modernidade.

Essa dualidade explica a coexistência, em Benjamin, de lados antimodernos e modernos, do Benjamin que denuncia a modernidade, atribuindo-lhe traços infernais, com o Benjamin que saúda o potencial revolucionário da técnica e da sensibilidade moderna. Não há contradiçäo, porque ele está falando de duas modernidades, a que é hostil ao homem e a que aponta um caminho para sua emancipaçäo. A modernidade é um telos e nesse sentido Benjamin é modernista; é uma perversảo, e nesse sentido ele é um crítico da modernidade; e é uma tarefa, e nesse sentido ele é um modernizador, movido pela vontade política de transformar a modemidade real à luz da modernidade teleológica, não por um processo gradativo de racionalização, mas por uma explosão brusca, apocalíptica, que introduza o reino da verdadeira modernidade - a messiânica.

A construçāo desse conceito "antiweberiano" de modernidade, em Benjamin, é evidentemente conjetural, o que não chega a ser um mal irreparável. Mas há boas c más conjeturas, e esta seria péssima se nāo houvesse algum indício de que Benjamin conhecia efetivamente a obra de Weber.

Felizmente esse indício aparece num texto recém-publicado. Entre os trabalhos

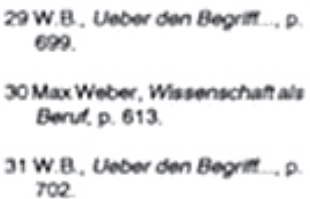


inéditos reunidos novol. VIdos Gesammelte Schriften há um curioso esboço de Benjamin, presumivelmente de 1921 , intitulado Capitalismo como Religiäo. Nele Benjamin sustenta que ocapitalismodeve servisto como uma religiāo, no sentido mais literal. É uma religião sem dogmas, que consta exclusivamente do culto, ou seja, a própria prática do capitalismo. Esse culto sem teologia é permanente, não conhece dias úteis, já que todos os dias da semana sāo dias santos. E é um culto que não visa a expiação, a atenuação da culpa, mas a culpabilizaçāo sistemática, crescente, cuja tendência é envolver a humanidade inteira, e em última instância arrastar Deus no universo da culpa. Esse texto é duplamente interessante.

Em primeiro lugar, ele constitui uma das primeiras fontes para a idéia de que o capitalismo, longe de ter contribuído para a secularização do mundo, reforçou, ao contrário, a esfera mítica. A formulaçäo, aqui, é mais radical. $\mathrm{O}$ capitalismo nāo levou apenas à "reativaçăo das forças míticas", como Benjamin diria no Trabalhodas Passagens, mas substituiu-se a elas, transformando-se ele próprio em religiâo.

Mas é sobretudo interessante porque a tese é articulada expressamente com referência a Weber e em oposiçāo a ele. Um dos pontos de partida dessa reflexão, segundo a bibliografiaanexada aoesboço, é justamente uma das obras de Weber mais ricas para a temática da modernidae, os Ensaios sobre a Sociologia da Religiāo. Benjamin defende a idéia da natureza religiosa do capitalismo distanciando-se da tese weberiana sobre as influências causais do calvinismo sobre ocapitalismo. Benjamin quer demonstrar "a estrutura religiosa do capitalismo, nāo somente, segundo opina Weber, como uma configuraçāo condicionada pela religiāo, mas como um fenômeno essencialmente religioso". Em outra referência polêmica a Weber, Benjamin diz mais adiante que, "na época da Reforma, o cristianismo nāo se limitou a favorecer a emergência do capitalismo, mastransformou-senele"(32).

Esse texto comprova, no mínimo, que Benjamin conhecia Weber e que, discordando dele, negava que a modernizaçāo capitalista tivesse abolido o universo religioso. Essa tese se tornaria decisiva no Trabalho das Passagens, como vimos. Como apenas seis anos separam o período de redação do esboço que estamos comentando da época em que Benjamin começou a to- mar suas primeiras notas para o Trabalho das Passagens, a hipótese deste artigo de que Benjamin construiu uma teoria da modernidade contra e a partir de Weber adquire alguma plausibilidade.

Podemos agora voltar à pergunta do simpósio. Ela é formulada com uma ambigüidade provocativa. "Moderno" pode ser interpretadoseja comosinônimode "novo", "atual" ou "contemporâneo", seja como sinônimode "modernidade", enquantoconfiguraçāo estrutural. No primeiro sentido, a pergunta é a seguinte: por que em nossa época tudo muda tāo rapidamente, por que o novo de ontem se transforma tâo depressa no antiquado de hoje? No segundo sentido, a questâoé outra: por que esse período a que chamamos modernidade, dotado de certas características estruturais (fé na razão e na ciência, moralidade secular, racionalidade empresarial, dominaçāoburocrático-legal), está envelhecendotão rapidamente? Háuma terceira pergunta, que sintetiza as outras duas: em que medida estaria envelhecendo essa época chamada modernidade, que entre suas características estruturais tem a de decretar o contínuo envelhecimento de todas as coisas? No primeiro caso, a questāo é o envelhecimento do novo; no segundo, o envelhecimentoda modernidade; no terceiro, oenvelhecimentoda modernidade como estrutura cujo princípio de funcionamento exige o contínuo envelhecimento do novo.

Benjamin responderia à primeira pergunta dizendo que é da essência da modernidade capitalista a eterna produção do novo e portanto a geraçăo incessante do velho. $\mathrm{O}$ "novo" é um afrodisíaco para estimular as vendas, e cada vez que esse elixir é aplicadoo novode ontemenvelhece, transformando-se em sucata temporal. Ao mesmo tempo, nesse mundo em que tudo se altera, tudopermanece idêntico, porque nāo muda a lógica do sistema: o novo está a serviço do mesmo.

Responderia à segunda pergunta contestando, em parte, o diagnóstico do qual ela deriva. $\mathrm{O}$ que está envelhecendo nâo é a modernidade como projeto, e sim uma forma específica de realização desse projeto. Nảoé a razão, a ciência e a liberdade que se tornaram obsoletas, e sim um certo uso da razão, da ciência e da liberdade. Em seu sentido normativo e teleológico, a modernidade não envelheceu, pela simples razāo de que nunca se realizou. A tarefa política é acelerar o envelhecimento da modernidade empírica, para abrir espaço à
W.B.. Kapitalismus Aeligion, GW, vol. VI, Frankhurt, Suhrkamp, 1986, pp. 100 - 102. 


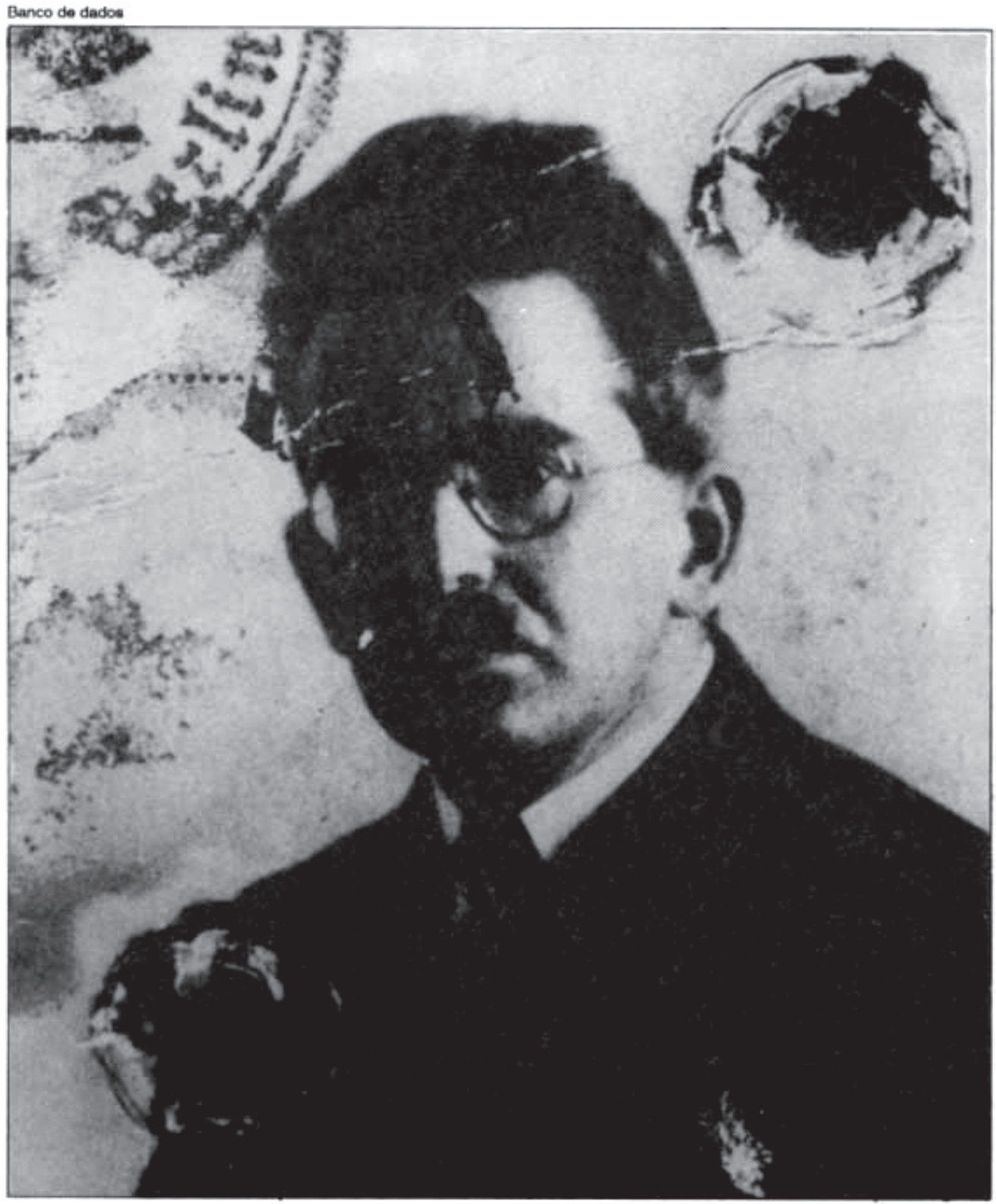

FOTO DO PASSAPOATE DE WE

modernidade normativa, com sua razão dialética, sua ciência libertadora e sua liberdade concreta.

Enfim, responderia à terceira perguntaadmitindoque ocontínuoenvelhecimento do "moderno" é um traço estrutural da "modernidade"; exprimindovotos paraque essa modernidade que se produz e reproduz pela obsolescência institucionalizada esteja efetivamente em declínio; e afirmando(talvez sem grande convicçāo) que numa modernidade futura, mais próxima da modernidade normativa, o homem estaria liberto da necessidade de produzir sistematicamente o novo e seu irmāo inimigo, o velho. Nessa modernidade, onovo o osempre igual deixariam de ser duas figuras da catástrofe, c passariam a ser os dois rostos da felicidade. Ser feliz é viver alegrias novas - é a felicidade como hino. Eé reviver alegrias antigas - a felicidade como elegia. No primeiro caso, a felicidade "é o inédito, o que năo foi nunca, a culminância da beatitude". No segundo, "é o eterno mais uma vez, a eterna restauraçāo da felicidade original, da primeira felicidade" (33).

A pergunta (ou as perguntas) do simpósiodirigem-se apenas à estrutura temporal da modernidade. Mas creio que a reconstruçāo proposta nesta palestra é suficientemente consistente para esclarecer, dentro do universo teórico de Walter Benjamin, outros aspectos da temática da modernidade.
33W.B. Dm Bilde Prousts, GS, Frankfurt, Suhrkamp, 1977. p. 313. 